IFAS Extension

\title{
Facts about Magnesium ${ }^{1}$
}

Jennifer Hillan and Linda B. Bobroff ${ }^{2}$

\section{Why do we need magnesium?}

Magnesium is a mineral needed by every cell in the body. Over 300 chemical reactions in the body require magnesium. Magnesium helps:

$\checkmark$ support normal muscle and nerve function

$\checkmark$ keep a steady heartbeat

$\checkmark$ keep bones strong

$\checkmark$ make protein and DNA

$\checkmark$ use energy from the foods we eat

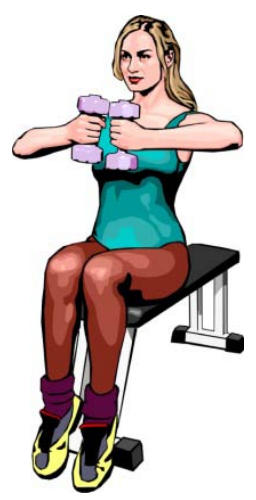

\section{What happens if we don't get enough magnesium?}

Many Americans don't get enough magnesium in their diets. While most healthy people do not have signs of deficiency because the body stores this mineral, people who abuse alcohol, take certain diuretic drugs, or have kidney disease may be at risk for magnesium deficiency. Long-lasting diarrhea or vomiting also can cause a deficiency. Older adults often do not get enough magnesium in their diets.
The following conditions can be signs of magnesium deficiency or other medical problems. Check with your doctor if you have:

$>$ appetite loss,

$>$ confusion,

$>$ abnormal heartbeat,

$>$ muscle cramps,

$>$ high blood pressure,

$>$ seizures.

\section{How much magnesium do we need?}

The following table lists recommended daily intakes of magnesium:

\begin{tabular}{|l|c|}
\hline \multicolumn{1}{|c|}{ Life Stage } & $\begin{array}{c}\text { Amount } \\
\text { (mg/day) }\end{array}$ \\
\hline Men, ages 19-30 & 400 \\
\hline Men, ages 31+ & 420 \\
\hline Women, ages 19-30 & 310 \\
\hline Women, ages 31+ & 320 \\
\hline Pregnancy, ages 19-30 & 350 \\
\hline Pregnancy, ages 31+ & 360 \\
\hline Breastfeeding, ages 19-30 & 310 \\
\hline Breastfeeding, ages 31+ & 320 \\
\hline mg = milligrams of magnesium \\
\hline
\end{tabular}

1. This document is FCS8810, one of a series of the Department of Family, Youth and Community Sciences, Florida Cooperative Extension Service, Institute of Food and Agricultural Sciences, University of Florida. Publication Date: April 2009. Please visit the EDIS Web site at http://edis.ifas.ufl.edu.

2. Jennifer Hillan, MSH, RD, LD/N, former ENAFS Nutrition Educator and Linda B. Bobroff, professor, Department of Family, Youth and Community Sciences, Institute of Food and Agricultural Sciences, University of Florida, Gainesville FL 32611. 


\section{How can we get enough magnesium?}

The best sources of magnesium are nuts, legumes, seeds, dark green vegetables, seafood, and whole grains. We can get enough magnesium by eating a variety of

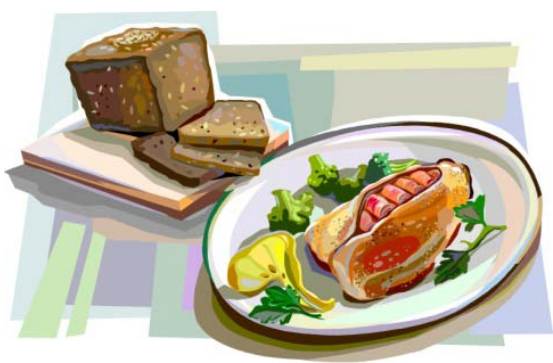
these foods every day. Some sources of "hard" water add magnesium to the diet.

Here are some foods and the amount of magnesium they contain:

\begin{tabular}{|l|c|}
\hline \multicolumn{1}{|c|}{ Food } & $\begin{array}{c}\text { Magnesium } \\
\text { (mg/serving) }\end{array}$ \\
\hline 100\% bran cereal, $1 / 2$ cup & 130 \\
\hline Avocado, Florida, 1 medium & 105 \\
\hline Sesame seeds, 1 ounce & 100 \\
\hline Wheat germ, toasted, $1 / 4$ cup & 95 \\
\hline Halibut, cooked, 3 ounces & 90 \\
\hline Almonds, dry roasted, 1 ounce & 85 \\
\hline Spinach, cooked, $1 / 2$ cup & 80 \\
\hline Black beans, cooked, $1 / 2$ cup & 60 \\
\hline Oatmeal, cooked, 1 cup & 55 \\
\hline Figs, dried, 5 & 55 \\
\hline $\begin{array}{l}\text { Potato, baked, with skin, } \\
\text { 1 medium }\end{array}$ & 55 \\
\hline Peanuts, dry roasted, 1 ounce & 50 \\
\hline Whole wheat bread, 2 slices & 50 \\
\hline Brown rice, cooked, $1 / 2$ cup & 45 \\
\hline mg = milligrams of magnesium & \\
\hline
\end{tabular}

\section{What about supplements?}

People who eat an adequate amount of a variety of healthy foods generally don't need magnesium supplements. However, people

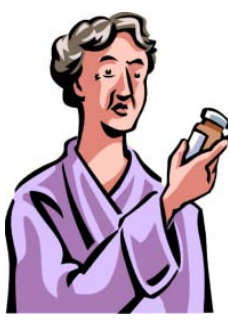 who have certain diseases or take certain medications may need extra magnesium. Your healthcare provider can tell you if you need to take a magnesium supplement.

\section{How much is too much?}

Magnesium is found in a number of overthe-counter drugs, including "milk of magnesia" and some antacids. Large doses of either these products or magnesium supplements can cause nausea, diarrhea, and stomach cramps. Magnesium from foods does not cause these symptoms. You should not get more than $350 \mathrm{mg}$ of magnesium per day from supplements or drugs.

\section{Where can I get more information?}

The Family and Consumer Sciences (FCS) agent at your county Extension office may have more written information for you as well as nutrition classes for you to attend. Also, a registered dietitian (RD) can provide reliable information to you.

Reliable nutrition information may be found on the Internet at the following sites: http://solutionsforyourlife.ufl.edu http://www.nal.usda.gov/fnic http://www.nutrition.gov http://mypyramid.gov 